The Levy Economics Institute

of Bard College
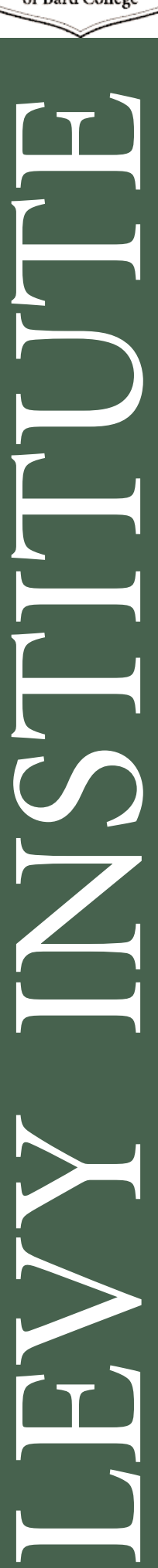

\section{Is Personal Debt Sustainable?}

\author{
Dimitri B. Papadimitriou, Anwar Shaikh, Claudio dos Santos, \\ and Gennaro Zezza
}

\section{INTRODUCTION}

Recent total government budget deficits, now running at about 3.4 percent of gross domestic product (GDP), have managed to partially rescue the U.S. economy from the full consequences of its long, debt-driven boom. But if we are to avoid a steep recession, much more will be needed.

The long economic expansion, dating from 1992 to 2000, was fueled by an unprecedented rise in private expenditure relative to income, financed by a growing flow of net credit to the private (household and business) sector. ${ }^{1}$ The ensuing boom was therefore attended by an unprecedented rise in the private sector's debt relative to its income. On the surface, it seemed as if the growing burden of the household sector's debt was counterbalanced by a spectacular rise in the relative value of its financial assets, but this was never a match between equals. On one side was a debt commitment that had to be met by actual flows of interest and repayments; on the other was a potential valuation compounded out of earnings, expectations, and illusions. It always seemed sensible to us that the two sides of this balance were fundamentally unequal (see, for example, Godley and Izurieta 2002, p. 8; Godley 1999, p. 6). ${ }^{2}$ We have consistently maintained, in the face of some skepticism, that such a process was unsustainable, that it would unravel, and that we were headed for a period of stagnation that could be offset only by a sufficiently forceful fiscal stimulus.

The great meltdown in the financial markets has proved us right. The private sector has dramatically cut back its acquisition of new credit and reversed the path of its financial balance. The most recently available figures indicate that its financial deficit moved from a high of 6.9 percent of disposable income in the third quarter of 2000 to 1.6 percent in the second quarter of 2002 (having dropped to 1 percent in the first quarter). However, this adjustment has been uneven within the private sector. The business sector, as exemplified by the corporate sector, suffered a huge drop in investment. Hence, it essentially stopped acquiring new debt even though interest rates reached their

The Levy Institute's Macro Modeling Team consists of Levy Institute President DIMITRI B. PAPADIMITRIOU, Senior Scholar ANWAR SHAIKH, and Research Scholars CLAUDIO DOS SANTOS and GENNARO ZEZZA. All questions and correspondence should be directed to Professor Papadimitriou at 845-758-7700 or dbp@levy.org. Helpful comments were provided by Distinguished Scholar WYNNE GODLEY and Research Associate ALEX IZURIETA. 
Chart 1

Balances of the Main Sectors

in Historical Perspective

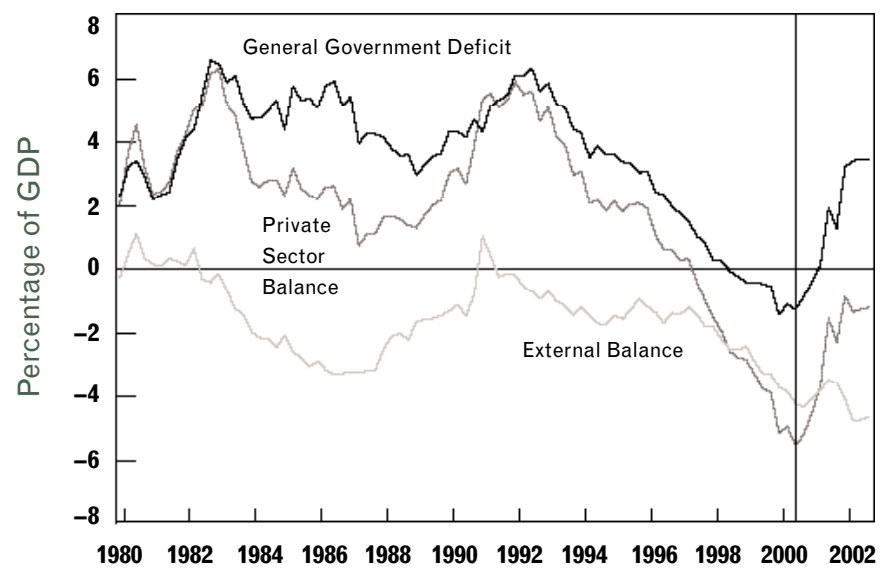

Sources: NIPA, Flow of Funds, and authors' calculations

Chart 2

Components of the Private Sector Balance in Historical Perspective

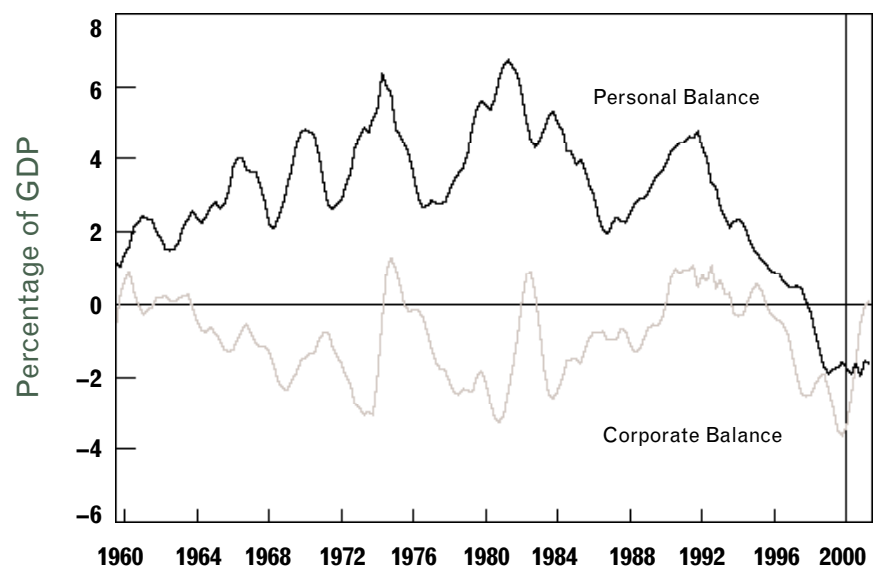

Sources: NIPA, Flow of Funds, and authors' calculations

lowest levels since the early 1960s. ${ }^{3}$ On the other hand, the household sector has continued to borrow, but even here, the overall trend of rates of net credit flows and financial balances seems to have leveled off since 2000.

With the private sector no longer willing-indeed, no longer able-to expand its net credit flows, the very stimulus that fueled the long boom has petered out. No counterweight can be sought in the foreign current account, which has long been in deficit and which even worsened sharply in 2002, reaching an unprecedented 4.7 percent of GDP in the second quarter. Preliminary data from the Bureau of Economic Analysis (BEA) for July and August indicate that the trade deficit has deteriorated even further since then (BEA 2002b); we project a third-quarter 2002 current account deficit of 4.8 percent of GDP. We are left with the government sector and, possibly, the net export demand portion of the foreign sector.

During the long boom, the general government deficit declined steadily, eventually giving way between 1998 and 2000 to the first set of postwar structural budget surpluses. Until quite recently, the Congressional Budget Office (CBO) projected increasing budget surpluses well into the future (CBO 2002a). We previously argued that if the government were to maintain such a restrictive fiscal stance as the private sector deficit inevitably began to return toward sustainable levels, a severe recession would follow. ${ }^{4}$ Conversely, we argued that in circumstances such as this, it was incumbent on the government to do its part to keep the economy from entering such a recession. With the growth rate of private expenditure declining and a surge in exports unlikely, a sharp rise in government expenditure would be the only means left to sustain adequate growth in aggregate demand. ${ }^{5}$

Indeed, this is what happened. Relative to GDP, the public sector balance declined sharply, from a surplus of 1.2 percent in the third quarter of 2000, at the peak of the expansion, to a deficit of 3.4 percent in the second quarter of 2002, a shift exceeding 4.5 percent of GDP in less than two years. We believe that this is a step in the right direction, and that it has served to stave off a much more severe recession. Clearly, however, more is needed. The public sector must move more aggressively in an expansionary direction. If net export demand could be improved, say, by a devaluation of the U.S. dollar, the size of the government deficit required to do the job would be correspondingly lower. ${ }^{6}$ In the following analysis, we explore the possible combinations of these two deficits that would serve to maintain the necessary levels of growth and employment.

\section{RECENT PATTERNS IN THE U.S. ECONOMY}

We begin by examining the recent patterns of the three main sectoral balances that compose the U.S. economy. As a matter of accounting, the ex-post government sector deficit, the current account surplus, and the private sector deficit (the excess of consumption and investment over private sector disposable income) must all add up to zero.

But ex ante, it is the excess of the sum of all demand injections less the leakages that drives growth (Papadimitriou and 
Wray 1998). Here, from 1992 to 2000 the injections from the government deficit declined, eventually turning into leakages as the government balance went to surplus in 1998. During the same period, the current account was in deficit; this particular leakage continued to escalate, reaching unprecedented levels. The result was a rise in private expenditure relative to incomewith an attendant rise in the private sector deficit and debt burden-as the major expansionary force. As long as the stock market boom offset personal sector debt, the process seemed endless. But, as noted earlier, this was an illusion; debt requires actual principal and interest repayments, which cannot be funded to any significant degree out of paper gains without causing the markets to decline and the gains to evaporate. In any case, the bubble burst at the end of 2000. In response, the private sector moved swiftly to curtail its expenditures and simultaneously reduce its net borrowing. Chart 1 traces these patterns in the three complementary balances. ${ }^{7}$

Chart 2 breaks down the private sector balance in Chart 1 into personal and corporate components (as percentages of GDP), each in terms of three-quarter moving averages. Although the corporate sector has rapidly returned to balance, the personal sector has merely stabilized its balance at a level that represents an ongoing deficit. This negative balance is far below the surplus maintained by the personal sector during most of the postwar period. ${ }^{8}$

The upshot of the spending boom is that personal sector debt burdens remain extraordinarily high (Chart 3). Nonetheless, the personal sector continues to borrow at a relatively high rate, although the trend seems to have stabilized (Chart 4). We have argued that such a process is unsustainable. Indeed, the most recent figures for household borrowing show that it dropped sharply in August 2002, posting its smallest gain in eight months. Wall Street analysts, who have generally been bullish in the past, are now concerned that this borrowing slowdown raises "worries about consumer spending ahead" (New York Times, "Growing in Borrowing Slowed in August," October $8,2002)$.

Chart 5 tracks the net wealth of the household sector, which is the balance between the stocks of its debt and its assets, relative to personal disposable income. Note the sharp drop in this measure starting in 1999, as the stock market began its downward spiral. This drop has been so steep that relative household net wealth has moved a considerable distance back toward its historical average.
Chart 3

Personal Sector Debt Outstanding

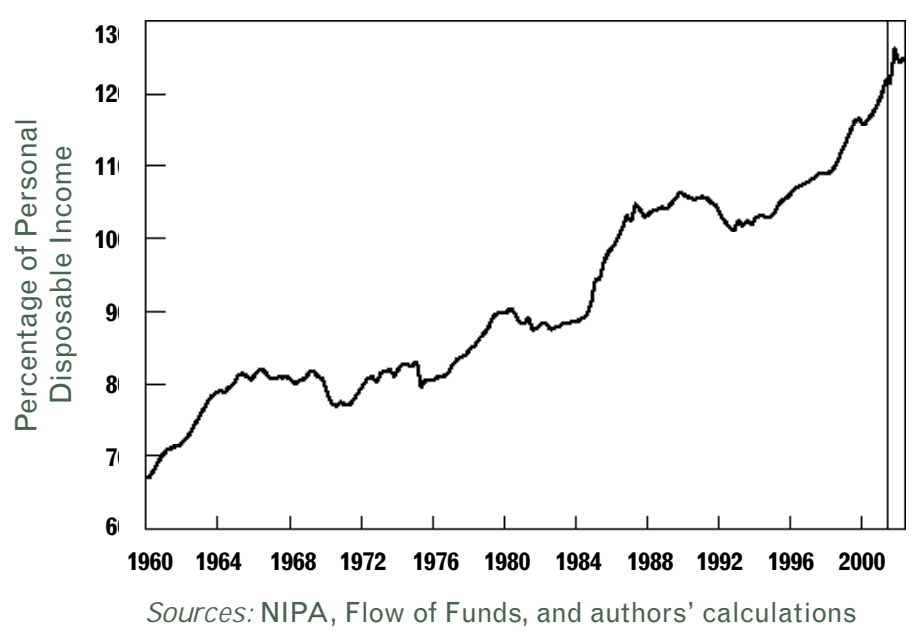

Chart 4

Personal Sector Financial Balance and Net Flow of Credit

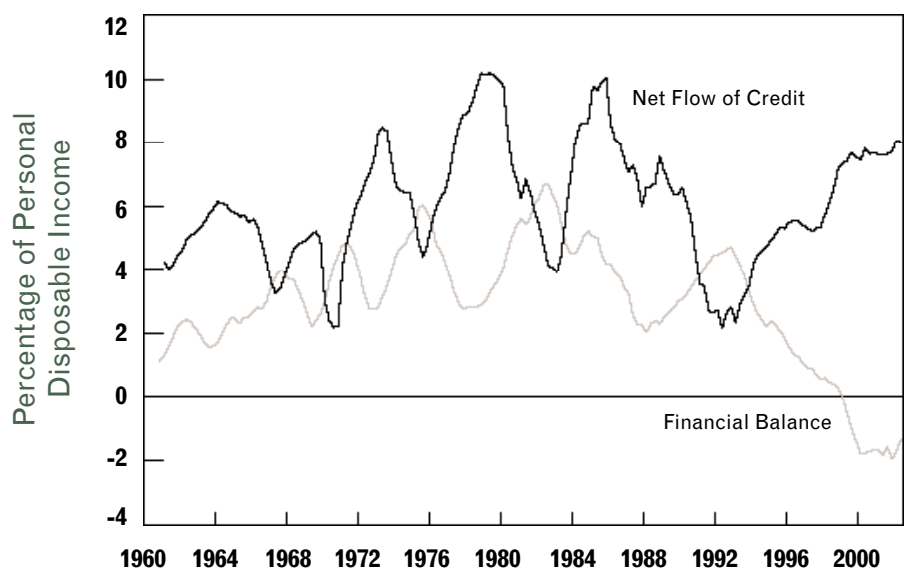

Sources: NIPA, Flow of Funds, and authors' calculations

Chart 5

Households' Net Worth Relative to

Personal Disposable Income

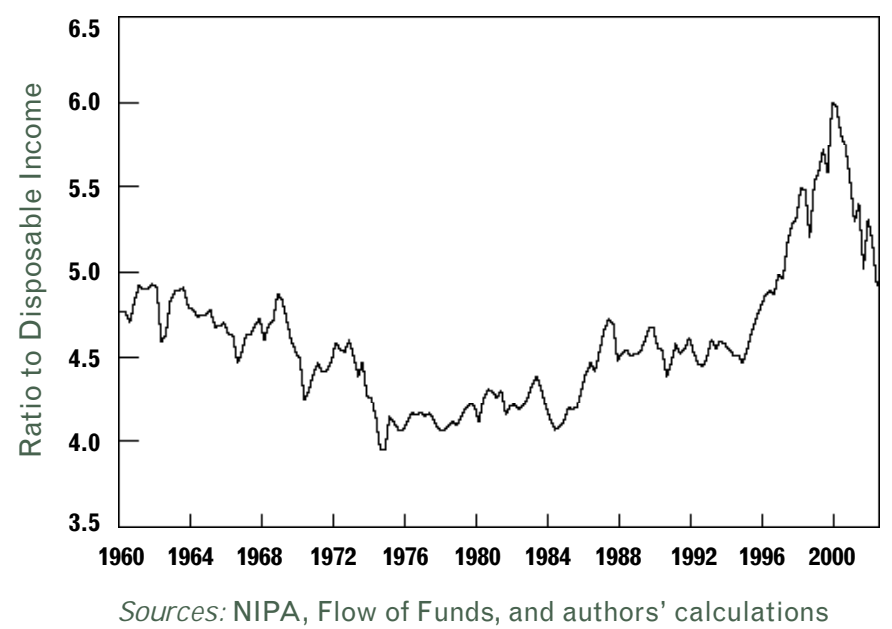


Chart 6

Components of Personal Sector Assets

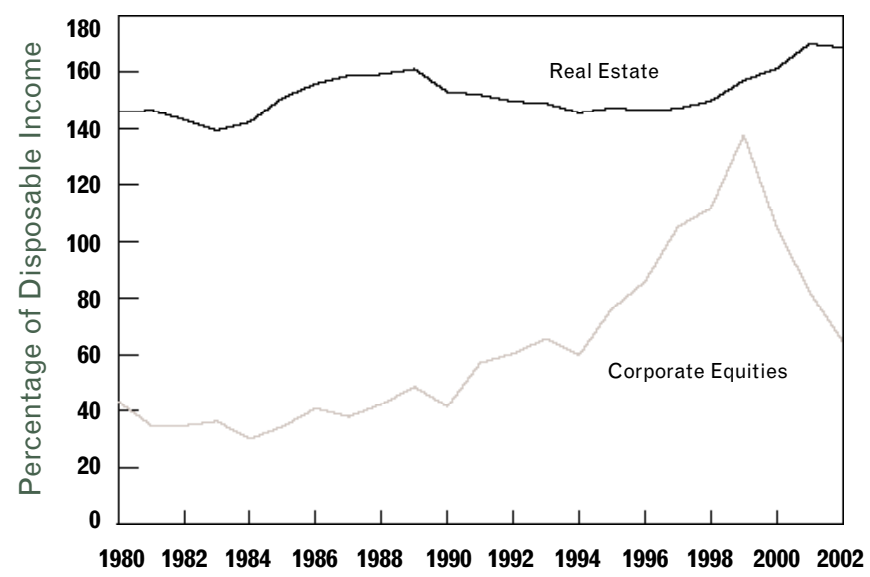

Sources: NIPA, Flow of Funds, and authors' calculations

Chart 7

Equities and Real Estate Relative Prices

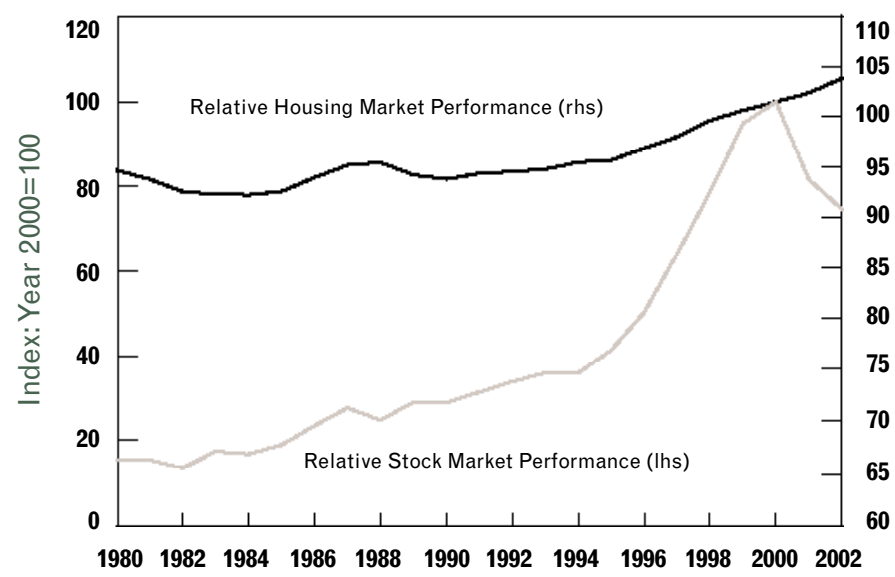

Sources: NIPA, Association of Realtors, Standard \& Poor's, and authors' calculations

It is interesting to note that two major components of the assets of the personal sector have so far moved in quite different ways. Although the value of the sector's equity holdings has declined sharply relative to its disposable income, the value of its real estate assets has continued to rise (Chart 6). That these two divergent effects are largely due to price effects is made clear in Chart 7, which depicts the relative prices of equities and housing. Finally, interest rates on household debt have fallen in line with the federal (fed) funds rate, which is itself at a historic low of 1.25 percent. All of this suggests that the full force of the personal sector's fall in net wealth has not yet been felt. Observers have recently expressed concern about the overheating housing market and record-level real estate prices (The
Economist, October 12, 2002, pp. 12-13). Should these prices begin to stagnate, or even to fall, it would have a significant negative impact on the borrowing capacity of households. Given the current low level of the fed funds rate, not much more room is left for monetary policy to counteract such an event.

It has long been our contention that such events were inevitable and would lead to a sharp slowdown in GDP growth unless they were sufficiently offset by demand injections elsewhere. While, others, too, have warned that the stock market boom of the 1990s reflected a departure from fundamentals, ${ }^{9}$ our focus throughout has been on the need to take the next step in the analysis: linking the potential deflation of financial markets to the ensuing fragility of the economy's debt structure. It was the buildup of this debt that fueled both the growth in real output and the stock market boom of the 1990s. It was this same debt buildup that eventually pushed the economy into a state of "financial fragility," as analyzed in the work of Levy Institute Distinguished Scholar Hyman P. Minsky. ${ }^{10}$ As our research has warned, the ensuing reaction over the last several years has unraveled both the stock market boom and real growth (Godley and Kregel 1998, Godley 1999). We have also consistently argued that in the face of a high and growing current account deficit, growth in aggregate demand could be sustained only by expansionary fiscal policy (Godley 2000).

The annualized trend of GDP growth, depicted here as the percentage change between a given quarter and its counterpart four quarters (one year) earlier, began to decline between the third quarter of 2000 and the second quarter of 2001 (Chart 8). This decline corresponds to a sharp deterioration in the private sector balance during this same period (Chart 1). Beginning in the second quarter of 2001, growth recovered to some degree, though it remained far below its potential. ${ }^{11}$ Why is even this partial recovery evident? In our view, it occurred largely because fiscal policy came to the rescue as the budget balance reversed itself, moving dramatically from a small surplus in the first quarter of 2000 to a substantial deficit of 3.4 percent of GDP by the second quarter of 2002 (Chart 1). ${ }^{12}$

The reappearance of public sector deficits, which we have long predicted, is all the more striking given that the $\mathrm{CBO}$ has long projected just the opposite. Chart 9 depicts historical figures up to 2001, as well as CBO projections of the fiscal balance for 2002 onward, made at successive dates from October 2000 to the most recent, in August 2002 (CBO 2000; 2001a,b; 
2002a,b). We discuss this in greater detail in the next section; for now it is sufficient to note that in arriving at these projections, the $\mathrm{CBO}$ makes specific assumptions (as opposed to forecasts) about key macroeconomic variables such as real GDP growth, inflation, and unemployment. In addition, the $\mathrm{CBO}$ projects only the federal deficit (so that a negative value is a surplus), whereas we depict the general government deficit implied by the federal deficit. ${ }^{13}$ It is striking that the CBO's projected deficits all display similar paths after 2002, moving steadily toward ever-larger surpluses. Over time, however, the slowdown in actual growth (whose severity was mitigated by the massive relaxation of fiscal policy after 2000) has forced the $\mathrm{CBO}$ to revise each successive estimate downward. Unless a sharper increase occurs in the public sector deficit, more such revisions will occur in the future. We have consistently argued that the CBO's projections were not plausible because they implied an unsustainable increase in the private sector deficit that would perforce be financed by further injections of credit, thereby increasing the private sector's debt burden. The limits of that process have now become evident, and over the last 17 months the $\mathrm{CBO}$ has had to revise its projections for 2002-06 downward by approximately $\$ 500$ billion per year.

As noted earlier, no relief can be expected from net export demand, since the current account portion of the balance of payments not only remains stubbornly in deficit, but has deteriorated sharply over the first two quarters of 2002, arriving at a new record of 4.7 percent of GDP. Past Levy Institute reports have shown that the decline in the balance of trade in manufactures accounts for the greater share of this pattern. It is evident that this is an unsustainable process because it implies a growing external debt burden that also must ultimately reach its limits. Chart 10 depicts the recent history of the current account balance, which is clearly driven by the primary balance. The recent modest reversal in the appreciation of the dollar evidently had little effect and was unable to prevent net property income abroad from falling considerably and even turning negative. This is to be expected, since a rising foreign debt burden should, ceteris paribus, imply a continuing shift in interest and dividend payments in favor of foreigners (Godley and Izurieta 2002, pp. 5-6).

Finally, it is worth noting that in recent times the public and foreign sectors have once more become reflections of each other (see Chart 1 for the period since mid 2001). In effect the economy is again approaching a period of "twin"
Chart 8

Growth of Real GDP (annual basis)

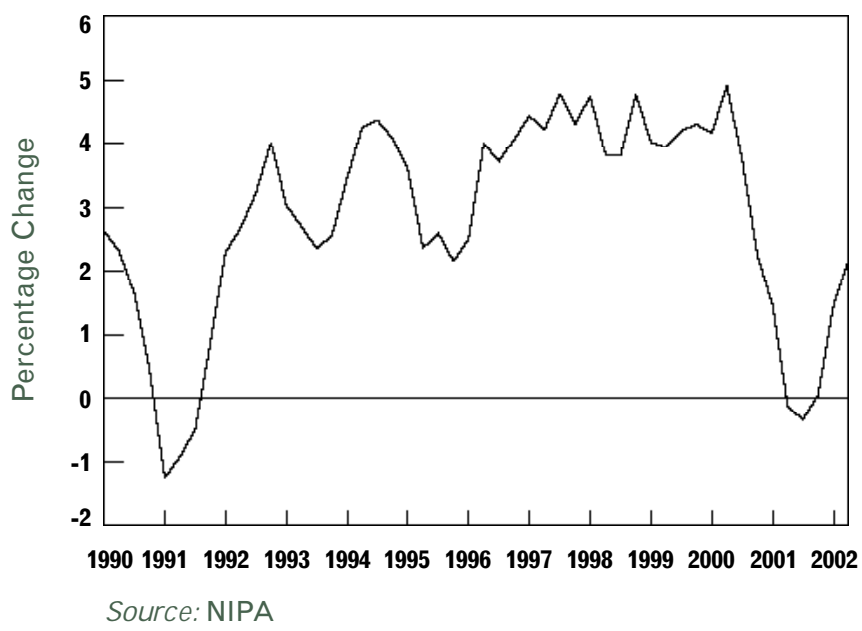

Chart 9

Federal Fiscal Deficit as Projected by the CBO

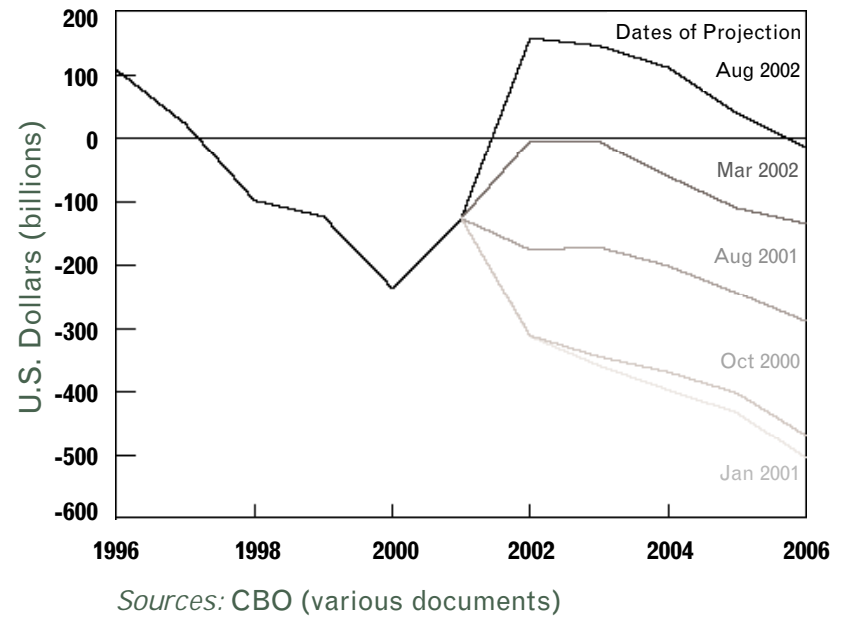

Chart 10

Current Account Balance Relative to GDP

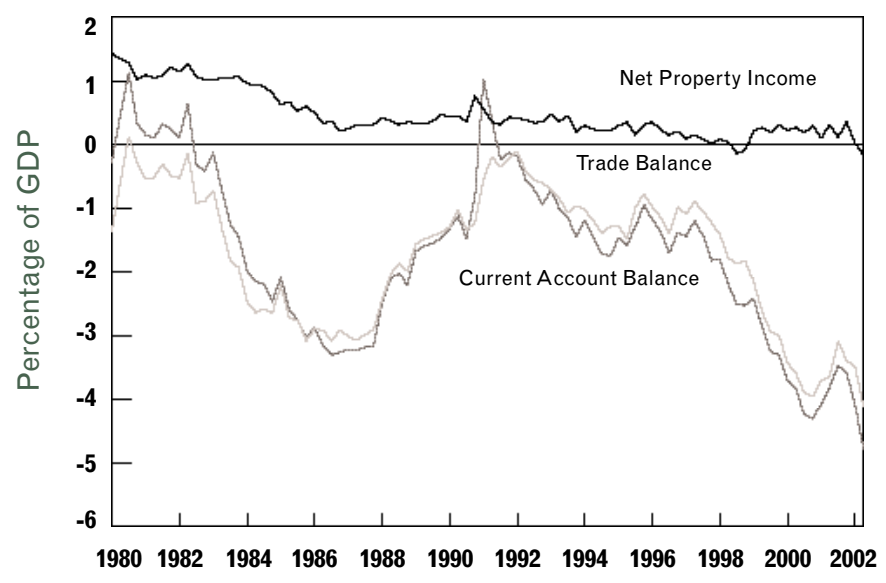

Sources: NIPA and authors' calculations 
deficits comparable to those of the 1980s and 1990s. ${ }^{14}$ We also anticipated this development, in a series of reports beginning in early 2001 (e.g., Godley and Izurieta 2001, 2002). Indeed, we have argued that the alternative to expanding the public deficit was a prolonged recession, and it was our belief that such an outcome would not have been politically feasible. Current events seem to have borne this out.

\section{AVOIDING A "HARD LANDING": SOME POLICY SCENARIOS}

As a matter of accounting, the ex-post government sector deficit, current account surplus, and private sector deficit (private sector disposable income less consumption and investment) must add up to zero. Given the complementary nature of the three main balances, the paths of any two will imply the ex-post path of the third. We can make use of this property first to discern what is likely to happen in the economy if the CBO's assumptions underlying its projections of future budget balances are to be realized. This is our baseline scenario, which tracks what the private sector must do in order to attain the CBO's projected growth path. We will then reverse the procedure and try to ascertain what the government deficit is likely to be if the private sector chooses a more plausible adjustment path. Finally, we will examine various alternative scenarios that could achieve the CBO's growth path via a combination of fiscal policy and significant improvement in net export demand.

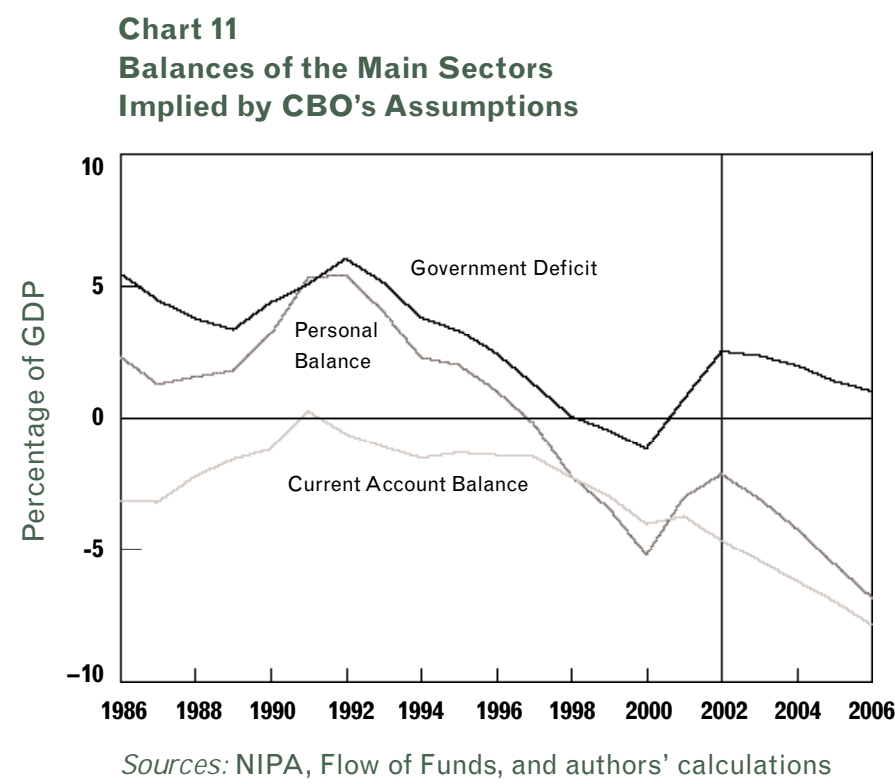

The Baseline Scenario: Sectoral Balances

\section{Implied by CBO Assumptions}

The first step is to construct what we call the baseline scenario. The aim here is to show what the private sector and foreign sector balances must be within our model if the CBO's projected fiscal balances, growth rates, and inflation rates are to be realized. The latest CBO projections (2002b) for the government deficit are shown in Chart 9. In addition to these, the CBO assumes that GDP will grow at 2.3 percent in 2002, 3 percent in 2003, and 3.2 percent on average from 2004 until 2007; and that inflation, as represented by the rate of change of the GDP deflator, will be 1.1 percent in 2002, 1.6 percent in 2003, and 2 percent on average from 2004 until 2007. To this we add the provisional assumptions that the nominal dollar exchange rate will remain constant and that world demand growth will rise moderately from its current low level. Chart 11 depicts this baseline scenario. The dark line represents the general government deficit corresponding to the $\mathrm{CBO}$ projection of the federal deficits, while the other two lines represent the relative surpluses of the private and foreign sectors implied by the CBO's assumptions. ${ }^{15}$ Note that in the case of the government sector, the deficit is depicted (so that a negative number represents a surplus), while for the private and foreign sectors, their surplus is shown (so that a negative number is a deficit).

The lower line in Chart 11 shows our conditional forecast of the current account balance, as a percentage of GDP, through 2006. This brings us to our central point. If, as in the CBO's latest projection, the present government deficit were to be pared to a surplus by 2006, the private sector would again have to run increasing deficits to generate the GDP growth projected by the CBO. This, in turn, would increase private indebtedness to new heights. It is hard to believe that after the collapse of equity prices, the private sector will return to a high and even rising level of indebtedness. Yet if the fiscal stance projected by the $\mathrm{CBO}$ were to be achieved, this is what must occur.

We therefore contend that a different policy is required. In order to achieve growth sufficient to maintain unemployment at reasonable levels, there must be substantial injections of new demand. This cannot come from the private sector, as it has in the past, because this same past has left the private sector with dangerously high levels of household and corporate debt. Hence it is the government sector that must assume the bulk of the burden. 
Scenario 1: Implications of CBO Fiscal Policy in the Face of a Projected Private Sector Balance by 2007

In the baseline scenario (Chart 11) we found that the private sector would have to run large deficits if the CBO's assumptions about growth were to be achieved in the face of its projections for the public sector fiscal stance (that is, for the tax rate and the growth of government spending). We now consider what would happen if instead the private sector continued on its present path and achieved eventual balance by 2007 . Given the same fiscal stance as before, we find that such a result would imply a lower rate of real GDP growth over the 2002-06 period, averaging about 1 percent per year. This lower growth rate, in turn, would imply lower tax revenues, so the government deficit would rise to almost 5 percent by 2006 (a figure within the range of the postwar average). ${ }^{16}$ Second, given that the three sectoral balances must add up to zero, the assumption that the private sector moves into balance implies that the public sector and the foreign sector must move in opposite directions. Thus the "twin" deficit in the foreign sector would also be around 5 percent, which is essentially its current level (see Chart 1). This is Scenario 1, depicted in Chart 12. But this scenario also implies a rise in unemployment, to around 7 percent by 2005 and 8 percent by 2006, which seems to us to be both undesirable and unsupportable.

\section{Scenario 2: Achieving CBO Growth via Budget Deficits}

We might now turn the question around and ask, What fiscal stance would be required to achieve the CBO's projected growth rates of real output? We retain the assumption that the private sector will continue to move toward balance. Given the high level of debt in the household sector, it is plausible that this sector will continue to pare its borrowing and perhaps even move toward net saving. On the other hand, the revival of growth on which this scenario is predicated is likely to stimulate further borrowing by the business sector to support its expansion. It is therefore plausible that the two effects would cancel each other out, so that growth of borrowing in the private sector as a whole would remain flat. Under these conditions, as depicted in Chart 13, we find that in order to achieve the CBO's growth targets, it would be necessary to have budget deficits rise sharply, to a level of over 8 percent by 2006. Such a level would be higher than the 4 to 5 percent postwar average, higher than the 6.5 percent level of the Reagan-Bush era, and higher still than the previous peak of 7.5 percent in 1975. Moreover, with the private sector moving into balance, the current account deficit would have to be of roughly the same order as the budget deficit. But the current account deficit (about 5 percent) is already at record levels, and its further deterioration to over 8 percent is surely unsustainable.

\section{Chart 12}

Alternative Scenario 1: Implications of CBO's Projected Fiscal Policy Assuming the Private Sector Approaches Balance

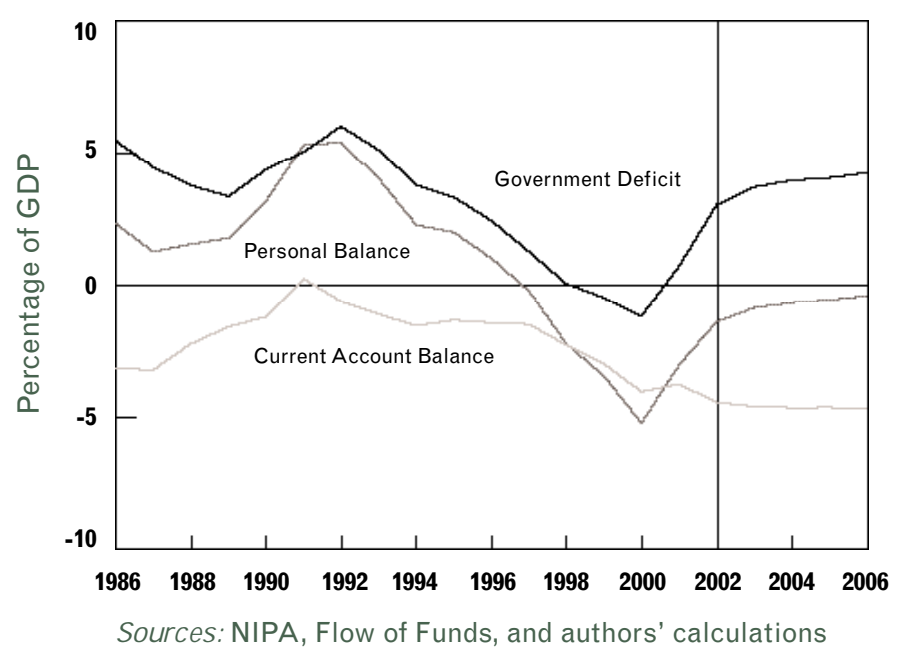

Chart 13

Alternative Scenario 2:

Fiscal Policy Required to Achieve CBO Growth Assuming the Private Sector Approaches Balance

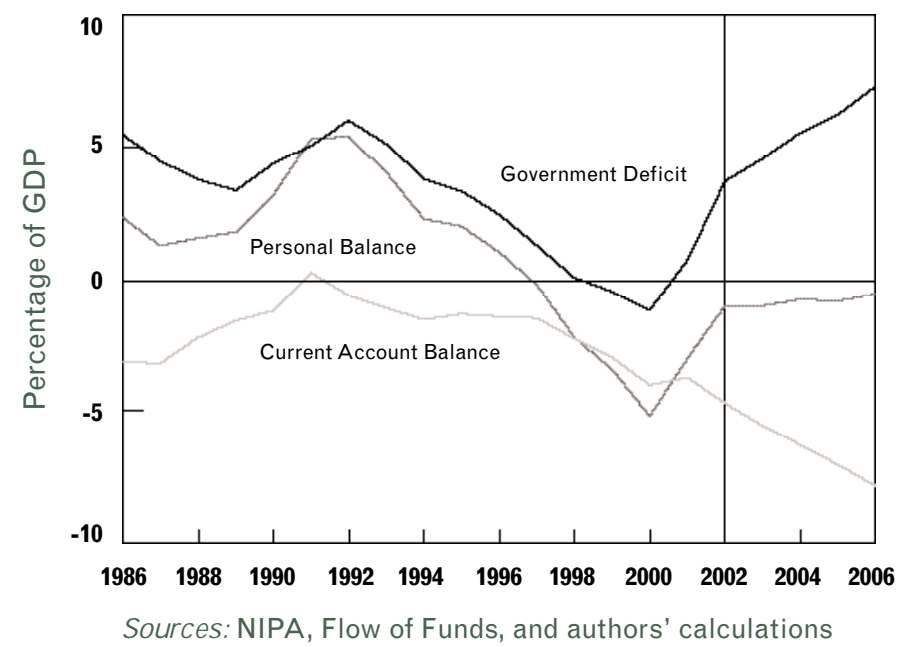

Sources: NIPA, Flow of Funds, and authors' calculations 
Scenario 3 (The Dream Scenario):

\section{Sustainable Balances}

If fiscal policy alone could not sustain growth and employment without unacceptable increases in both budget and current account deficits, where else might we turn? The answer lies in what we have previously called our dream scenario: an improvement in net export demand sufficient to achieve CBO projected growth and, hence, employment, without relatively large budget deficits.

In all of our previous simulations we provisionally assumed that the exchange rate remained unchanged and that real exports grew at 1 percent per year. But we believe, as do others (Bergsten 2002), that net export demand could be raised substantially by means of a devaluation of the effective exchange rate, of around 25 percent, at the beginning of 2003. This would reverse the present trend of the current account, bringing it close to a sustainable level of 2 to 2.5 percent of GDP by 2006. With the private sector itself assumed to be approaching balance, this would imply that the government sector would also move toward balance. Thus all three sectors could return to sustainable balances, while still achieving desired levels of employment and growth. This felicitous combination is described in Scenario 3, depicted in Chart 14.

We are aware that the policy scenario we propose is by no means an easy one to achieve. With the advent of flexible exchange rates, devaluations are no longer a standard policy

\section{Chart 14}

Alternative Scenario 3:

Fiscal Policy and Export Growth Required to Achieve CBO Growth Assuming All Sectors Approach Balance

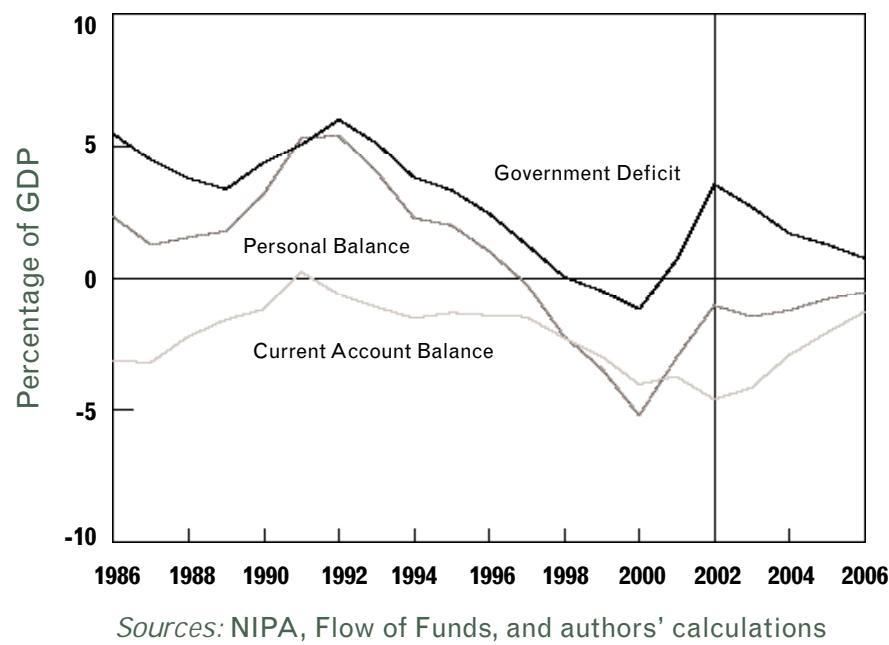

instrument. Since 1998, growing current account deficits have not led to any substantial depreciation of the dollar, other than a modest fall in the first half of 2002. Indeed, the deficit has not even reacted in the usual manner to the latest decline in U.S. growth (such as in the third quarter of 2002), which should have slowed the growth of imports and hence reduced the deficit. Instead, both the trade balance and the current account deteriorated even further. We recognize that devaluation on the order of 25 percent would raise import prices and thus might stimulate a general price rise. But our estimates indicate that this effect would be fairly modest, and we draw confidence from the fact that a much larger depreciation in the mid 1980s was not attended by a significant rise in inflation.

However, the consequences for foreigners of a substantial improvement in the U.S. current account balance are much more serious. Other things being equal, such an improvement would imply a decline in relative net export demand by the rest of the world, with a corresponding decline in its levels of output and employment. This, in turn, would inevitably affect our own export growth and, as a result, our output and employment growth. The only solution, therefore, is for our trading partners to shoulder part of the burden of fueling worldwide growth by undertaking their own expansionary measures at the same time. The U.S. net trade deficit has long provided a stimulus to its trading partners, but the record levels of its current account deficit signal the approaching end of that process. What therefore seems to be required is a coordinated expansionary effort on an international scale, with a greater share taken up by the rest of the developed world. The alternative is a severe growth recession and a steep rise in unemployment in the United States and, most likely, the rest of the world.

\section{CONCLUSIONS}

Economic growth from 1992 to 2000 was largely fueled by a spectacular rise in net lending to the private sector (Chart 4). We have argued in the past that the borrowing frenzy and its concomitant buildup of debt, which had fueled both the growth in real output and the stock market boom of the 1990s, was pushing the economy into a Minskian state of financial fragility. Others had also warned about the unsustainability of the boom in the latter part of the 1990s, particularly with regard to the stock market. Our particular concern 
has always been that the potential deflation of financial markets could also unravel real growth, which is precisely what happened. The equally spectacular rise in the value of financial assets that sustained private sector net worth melted away (Charts 5-7), and the private (business and personal) sector responded by cutting back its acquisition of further debt (Chart 1). In the face of these events, the trend of the GDP growth rate declined sharply from the third quarter of 2000 to the second quarter of 2001 (Chart 8).

From the second quarter of 2001 forward, real GDP growth made a partial recovery, although it reached only half the average rate achieved during the previous expansion. This partial recovery, far too modest to sustain employment, took place only because the small budget surplus in the first quarter of 2000 reversed itself dramatically, becoming a deficit of nearly 4 percent of GDP (Chart 1). We had consistently advocated just such a reversal in fiscal policy near the end of the 1992 debt-fueled expansion. This reappearance of public sector deficits was evidently a surprise to the $\mathrm{CBO}$, which had steadfastly projected substantial surpluses, only to successively revise these projections downward in light of actual events (Chart 9). Over the last 17 months the $\mathrm{CBO}$ has had to revise its projections for the 2002-06 period downward by $\$ 500$ billion per year.

While the current fiscal policy has moved in the right direction, we believe that it is far from sufficient. To substantiate this conviction, we examine four alternative policy scenarios.

We call the first alternative our Baseline Scenario, which is depicted in Chart 11. In this scenario we show that in order to realize the CBO's latest projected growth rates and fiscal balances within our model, the private sector would again have to run increasing deficits and raise its indebtedness to new heights. We have argued in the past (and argue more urgently now) that since even current private sector debt burdens are unsustainable, the prospect of their further escalation is not feasible.

Consequently, we turn to Scenario 1, depicted in Chart 12. Here we retain the latest $\mathrm{CBO}$ assumptions about the government's fiscal stance (tax rates and spending plans) and supplement them with the assumption that the private sector will continue on its present path toward decreasing deficits, culminating in eventual balance by 2007 . We find that under these circumstances, real GDP growth would average about 1 percent over the 2002-07 period, with associated levels of unemployment on the order of 7 to 8 percent. This, in turn, would imply lower tax revenues, thereby raising the government deficit to almost 5 percent of GDP by 2007 (which is within the range of the postwar average) and keeping the current account deficit at roughly its present level, about 5 percent. This shows that the CBO's assumptions about the fiscal stance are not only incompatible with its assumptions about growth and employment, but would result in undesirable economic outcomes.

In Scenario 2 of Chart 13, we consider which fiscal stance is required to achieve the CBO's assumptions on growth, retaining the assumption that the private sector will continue to move toward balance. This leads us to conclude that achieving the CBO's growth targets would require sharply higher budget deficits, on the order of 8 percent of GDP by 2007 . Assuming that the private sector moves toward balance, this would require a correspondingly large "twin" deficit in the current account balance. Both of these deficits would be significantly higher than the present and postwar averages, and even higher than past postwar peaks. We conclude that sustaining growth and employment through fiscal policy alone is simply not feasible.

Finally, we turn to Scenario 3 (Chart 14), which we call our dream scenario. In it we allow for the possibility of substantial improvement in net export demand resulting from a devaluation of the dollar of about 25 percent. This would require a much smaller initial budget deficit in order to realize the levels of real GDP growth assumed by the CBO. Indeed, over time the resulting GDP growth would reverse the directions of both the public sector and current account deficits, so that both, along with the private sector, would approach sustainable levels by 2007 . Thus the combined effects of a devaluation and an expansionary fiscal policy could achieve desired levels of employment and growth while also restoring each sector to a better balance. Given the present high levels of sectoral debt burdens, this latter possibility is of great significance.

We recognize that the fiscal and trade policies we propose are by no means easily implemented, particularly in light of their probable global repercussions. We also realize that fiscal conservatives may react disapprovingly to the reappearance of the "twin" deficits that seem inevitable to us in the short run. But we believe that the alternative-a severe recession with a significant rise in unemployment-is surely unacceptable to all concerned. 


\section{NOTES}

1. The private sector consists of the household and business sectors. The latter, in turn, is made up of the noncorporate and nonprofit enterprises and the corporate sector.

2. It is remarkable how often analysts tend to forget that debts have to be paid, whereas the capital gains that appear to offset them cannot be realized in any significant amount by the private sector as a whole without causing the markets to crash and gains to disappear.

3. The latest round of interest rate cuts has reduced the federal funds rate to 1.25 percent and the discount rate to 0.75 percent. The limits of monetary policy are now widely acknowledged.

4. A severe recession would be tantamount to a "debt crisis" in the sense of Minsky (1982, 1986).

5. The consensus in the last decade has been that the U.S. expansion was solid because it was grounded in supply-side factors such as the technological dynamism of the economy and flexibility in the labor market. From this point of view, government intervention is neither necessary nor desirable, because the market is always self-righting. Against this consensus, the Levy Institute has long recommended a recourse to fiscal policy when appropriate (Papadimitriou and Wray 1998; Godley 1999; Godley and Izurieta 2001, 2002).

6. As a matter of accounting, if the private sector is in balance, the government deficit must equal the foreign deficit.

7. In this chart, a negative government balance represents a surplus. The other balances are more intuitive, in the sense that positive numbers imply surpluses.

8. Using quarterly data for the period of the recent expansion (the second quarter of 1992 through the third quarter of 2000), the personal sector balance declined steadily, from an initial surplus of 4.5 percent of GDP to a significant deficit of 1.7 percent. The balance continued to fall somewhat erratically during the first two quarters of 2001, then underwent a swift upturn during the third quarter, due to the positive impact of the tax rebate on disposable income. It fell once again in the last quarter of 2001, as households spent previous windfall gains and were encouraged by zero-percent interest rates on the purchase of durable goods.

9. Many analysts have come to adopt Robert Shiller's (2000) view that the stock market boom of the late 1990s was driven by "irrational exuberance."

10. The classic references are Minsky $(1982,1986)$. For a concise summary, see Minsky (1991, especially footnote 51).

11. The most recent preliminary estimates for the third quarter of 2002 show real GDP growth of 4.0 percent at an annualized, seasonally adjusted rate (1.3 percent growth in the preceding quarter). Such estimates are typically subject to considerable revision.
More important, because the apparent growth surge has been led almost exclusively by the growth in personal consumption expenditures, most commentators now agree with our opinion that such a growth rate is unsustainable in the face of record levels of household debt (Financial Times, "US Economy Still Troubled Despite Bright Spots," October 31, 2002).

12. The BEA (2002a) states that "both the previously published and the revised estimates show GDP growth peaking in the fourth quarter of 1999 and slowing substantially during the quarters of 2000. However, the revised estimates show declines in GDP for each of the first three quarters of 2001, whereas the previously published estimates showed positive but decelerating growth in the first half of 2001 and a decline in the third quarter. Both sets of estimates show GDP growth resuming in the fourth quarter of 2001."

13. To derive the general government deficit from the federal deficit, we adapted the CBO's projection using a scaling factor derived from the past (fairly stable) relationship between the federal budget and the surplus or deficit in the general government.

14. For details, see Godley (1995).

15. We scale up the federal budget balance to obtain the implicit general government balance using historical patterns between the two.

16. In addition, a small increase in government expenditure arises in Scenario 1, due to the higher projected level of unemployment.

\section{REFERENCES}

Bergsten, Fred. 2002. “Let the Dollar Fall." Financial Times, Personal View. July 18.

Bureau of Economic Analysis. 2002a. "National Income and Product Accounts: Second Quarter 2002 GDP (Advance) Revised Estimates.” July 31.

—. 2002b. "U.S. International Trade in Goods and Services: August 2002." October 18.

- 2002c. "National Income and Product Accounts: Third Quarter 2002 GDP (Advance) Revised Estimates.” October 31.

Congressional Budget Office. 2000. "The Long-Term Budget Outlook." October.

—. 2001a. "The Budget and Economic Outlook: Fiscal Years 2002-2011.” January.

—. 2001b. "The Budget and Economic Outlook: An Update." August.

—. 2002a. "The Budget and Economic Outlook: Fiscal Years 2003-2012.” January.

—. 2002b. "The Budget and Economic Outlook: An Update." August. 
Godley, Wynne. 1995. "U.S. Foreign Trade, the Budget Deficit, and Strategic Policy Problems: A Background Brief.” Working Paper no. 138. Annandale-on-Hudson, N.Y.: The Levy Economics Institute.

- 1999. Seven Unsustainable Processes: Medium-Term Prospects and Policies for the United States and the World. Strategic Analysis. Annandale-on-Hudson, N.Y.: The Levy Economics Institute.

- 2000. Interim Report: Notes on the U.S. Trade and Balance of Payments Deficits. Strategic Analysis. Annandale-on-Hudson, N.Y.: The Levy Economics Institute.

Godley, Wynne, and Alex Izurieta. 2001. "As The Implosion Begins . .. ? Prospects and Policies for the U.S. Economy: A Strategic View. Strategic Analysis. Annandale-on-Hudson, N.Y.: The Levy Economics Institute.

- 2002. Strategic Prospects and Policies for the U.S. Economy. Strategic Analysis. Annandale-on-Hudson, N.Y.: The Levy Economics Institute.

Godley, Wynne, and Jan Kregel. 1998. "Levy Bulletin on the Real Effects of the Asian Crisis." Briefing Paper. http://www.levy.org/ whatsnew/congress/031098levy.html.

Minsky, Hyman P. 1982. Can "It" Happen Again? Essays on Instability and Finance. Armonk, N.Y.: M.E. Sharpe.

- 1986. Stabilizing an Unstable Economy. New Haven, Conn.: Yale University Press.

—. 1991. "Financial Crises: Systemic or Idiosyncratic?" Working Paper no. 51. Annandale-on-Hudson, N.Y. The Levy Economics Institute.

Papadimitriou, Dimitri B., and L. Randall Wray. 1998. What to Do with the Surplus: Fiscal Policy and the Coming Recession. Policy Note 1998/6. Annandale-on-Hudson, N.Y.: The Levy Economics Institute.

Shiller, Robert J. 2000. Irrational Exuberance. New York: Broadway Books.

\section{RECENT LEVY INSTITUTE PUBLICATIONS}

\section{WORKING PAPERS}

Managed Care, Physician Incentives, and Norms of Medical

Practice: Racing to the Bottom or Pulling to the Top?

DAVID J. COOPER AND JAMES B. REBITZER

No. 353, September 2002

Should Banks Be "Narrowed"?

BIAGIO BOSSONE

No. 354, September 2002

Can Monetary Policy Affect the Real Economy?

PHILIP ARESTIS AND MALCOLM SAWYER

No. 355, September 2002
Asset Poverty in the United States, 1984-1999: Evidence from the Panel Study of Income Dynamics

ASENA CANER AND EDWARD N. WOLFF

No. 356, September 2002

\section{POLICY NOTES}

Hard Times, Easy Money? Countercyclical Stabilization in an Uncertain Economy

ROBERT E. CARPENTER

$2001 / 9$

Are We All Keynesians (Again)?

DIMITRI B. PAPADIMITRIOU and L. RANDALL WRAY

2001/10

Kick-Start Strategy Fails to Fire Sputtering U.S. Economic Motor WYNNE GODLEY

$2002 / 1$

The Brazilian Swindle and the Larger

International Monetary Problem

JAMES K. GALBRAITH

$2002 / 2$

European Integration and the "Euro Project"

PHILIP ARESTIS AND MALCOLM SAWYER

$2002 / 3$

\section{PUBLIC POLICY BRIEFS}

Easy Money through the Back Door

The Markets vs. the ECB

JÖRG BIBOW

No. 65, 2001 (Highlights, No. 65A)

\section{Racial Wealth Disparities}

Is the Gap Closing?

EDWARD N. WOLFF

No. 66, 2001 (Highlights, No. 66A)

\section{The Economic Consequences of German Unification}

The Impact of Misguided Macroeconomic Policies

JÖRG BIBOW

No. 67, 2001 (Highlights, No. 67A)

\section{Optimal CRA Reform}

Balancing Government Regulation and Market Forces KENNETH H. THOMAS

No. 68, 2002 (Highlights, No. 68A)

Should Banks Be "Narrowed"?

An Evaluation of a Plan to Reduce Financial Instability

BIAGIO BOSSONE

No. 69, 2002 (Highlights, No. 69) 


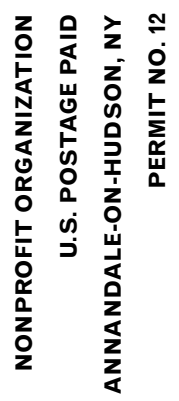
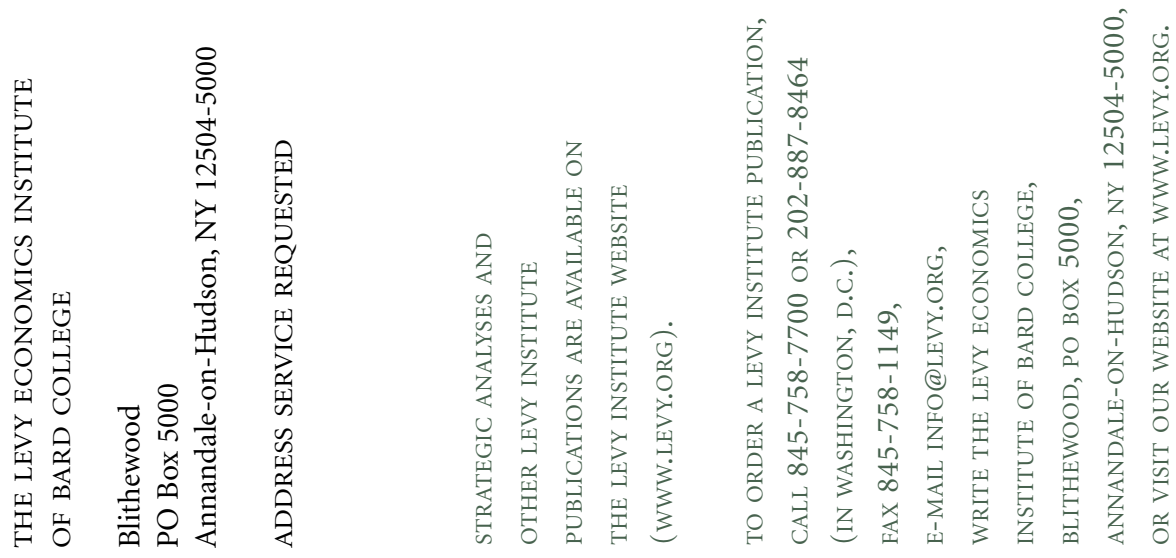